\title{
SUHU DAN KELEMBAPAN TANAH PADA POSISI TOPOGRAFI DAN KEDALAMAN TANAH BERBEDA DI TAMAN SEJATI KOTA SAMARINDA
}

\author{
Suci Rahmatika Cahyaningprastiwi ${ }^{1}$, Karyati ${ }^{2}$, Sri Sarminah ${ }^{2}$ \\ ${ }^{1}$ UPTD KPHP Mook Manor Bulatn, Jalan Jenderal A. Yani RT. XI Melak Ulu, Melak, \\ Kabupaten Kutai Barat, 75765 \\ ${ }^{2}$ Fakultas Kehutanan, Universitas Mulawarman, Jalan Penajam, Samarinda, \\ Provinsi Kalimantan Timur, Indonesia, 75119 Telp. (0541) 735089, 749068 Fax. \\ 735379 \\ Email: sucirahmatika111213@gmail.com; karyati@fahutan.unmul.ac.id
}

\begin{abstract}
ABSTRAK
Suhu dan Kelembapan Tanah pada Posisi Topografi dan Kedalaman Tanah Berbeda di Taman Sejati Kota Samarinda. Keberadaan taman kota mempunyai fungsi yang sangat penting bagi suatu kota, baik fungsi ekologis, estetika, dan ekonomis. Tujuan penelitian ini untuk mengetahui karakteristik suhu dan kelembapan pada posisi topografi berbeda (puncak, lereng, dan lembah) dan kedalaman tanah berbeda $(5 \mathrm{~cm}$, $10 \mathrm{~cm}$, dan $20 \mathrm{~cm}$ ) di Taman Sejati, Kota Samarinda. Pengukuran suhu dan kelembapan tanah dilakukan pada tiga waktu (pagi hari pukul 07.00-08.00 WITA, siang hari pukul 12.00-13.00 WITA, dan sore hari pukul 17.00-18.00 WITA) selama 30 hari dengan menggunakan alat Environment meter merk Krisbow KW06-291. Suhu tanah rataan pada kedalaman $5 \mathrm{~cm}, 10 \mathrm{~cm}$, dan $20 \mathrm{~cm}$ yang terukur di posisi puncak berkisar $27,8-30,0^{\circ} \mathrm{C}$, di posisi lereng berkisar $27,6-30,4^{\circ} \mathrm{C}$, dan di posisi lembah berkisar $28,6-31,4^{\circ} \mathrm{C}$. Sedangkan kelembapan tanah rataan pada kedalaman $5 \mathrm{~cm}, 10 \mathrm{~cm}$, dan $20 \mathrm{~cm}$ di puncak, lereng, dan lembah masing-masing berkisar 72,8-90,0\%, 64,9-89,7\%, dan 67,0-88,7\%. Perbedaan karakteristik suhu dan kelembapan tanah dipengaruhi oleh posisi topografi dan kedalaman tanah. Informasi karakteristik suhu dan kelembapan tanah bermanfaat untuk pengelolaan vegetasi dan tanah, terutama dalam pemilihan jenis-jenis tanaman yang sesuai pada topografi berbeda di taman kota.
\end{abstract}

Kata kunci: Kelembapan tanah, Samarinda, suhu tanah, taman kota.

\begin{abstract}
Soil Temperature and Humidity at Different Topographic Position and Soil Depths in Taman Sejati Samarinda City. The existence of city parks has a very important function for a city, both ecological, aesthetic, and economic functions. The purpose of this study was to determine the characteristics of temperature and humidity at different topographic positions (peaks, slopes, and valleys) and soil depths (5 $\mathrm{cm}, 10 \mathrm{~cm}$, and $20 \mathrm{~cm}$ ) in Taman Sejati, Samarinda City. Measurement of soil temperature and humidity was carried out at three times (morning 07.00-08.00 WITA, afternoon 12.00-13.00 WITA, and afternoon 17.0018.00 WITA) for 30 days using the Environment meter Krisbow KW06-291. The average soil temperature at a depth of $5 \mathrm{~cm}, 10 \mathrm{~cm}$, and $20 \mathrm{~cm}$ measured at top position ranged $27.8-30.0^{\circ} \mathrm{C}$, at slopes position ranged $27.6-30.4^{\circ} \mathrm{C}$, and at valleys position ranged 28.6 to $31.4^{\circ} \mathrm{C}$. Meanwhile the average soil moisture at a depth of $5 \mathrm{~cm}, 10 \mathrm{~cm}$, and $20 \mathrm{~cm}$ at the top, slope, and valley positions ranged from $72.8-90.0 \%, 64.9-89.7 \%$, and $67.0-88.7 \%$, respectively. The differences in soil temperature and moisture characteristics are influenced by topographic position and soil depth. Information on soil temperature and moisture characteristics is useful to manage vegetation and soil, especially in selecting suitable plant species for different topography in city parks.
\end{abstract}

Key words: city park, Samarinda, Soil humidity, soil temperature. 


\section{PENDAHULUAN}

Taman kota adalah lahan terbuka yang mempunyai fungsi sosial dan estetik sebagai sarana kegiatan rekreatif, edukasi atau kegiatan lain pada tingkat kota. Taman kota ditujukan untuk melayani penduduk satu kota atau bagian wilayah kota. Taman ini melayani minimal 480.000 penduduk dengan standar minimal $0,3 \mathrm{~m}^{2}$ per penduduk kota, dengan luas taman minimal $144.000 \mathrm{~m}^{2}$ (Peraturan Menteri Pekerjaan Umum Nomor 05/PRT/M/2008). Taman kota yang biasanya ditumbuhi berbagai jenis tanaman mempunyai banyak fungsi penting, diantaranya fungsi ekologis sebagai paru-paru kota dan pengatur iklim mikro. Imansari dan Khadiyanta (2015) melaporkan masyarakat pengguna Ruang Terbuka Hijau (RTH) publik lebih menginginkan RTH publik yang berfungsi sebagai peneduh dan paru-paru kota. Keberadaan taman kota yang memadai di setiap perkotaan berpengaruh terhadap kenyamanan suatu kawasan. Semakin banyak jumlah taman kota yang dibangun akan meningkatkan kenyamanan perkotaan dari aspek iklim mikro (Sanger, dkk., 2016).

Keberadaan tumbuhan pada hutan kota dan RTH mempengaruhi iklim mikro baik, iklim di atas permukaan tanah maupun iklim di bawah permukaan tanah. Unsur iklim di bawah permukaan tanah tersebut diantaranya suhu dan kelembapan tanah. Aalto, dkk. (2013) menyebutkan bahwa vegetasi memiliki peran penting dalam mempengaruhi variasi suhu dan kelembapan tanah pada skala spasial mikro pada suatu ekosistem. Suhu tanah bervariasi secara musiman dan harian yang dapat disebabkan oleh perubahan energi radiasi dan perubahan energi tersebut terjadi melalui permukaan tanah (Onwuka dan Mang, 2018). Lubis (2007) menyatakan suhu tanah berpengaruh terhadap penyerapan air dimana saat terjadi penurunan suhu tanah mendadak akan menyebabkan kelayuan tanaman. Arnold (1999) mengemukakan kelembapan tanah merupakan salah satu variabel kunci dalam perubahan air dan energi panas di antara permukaan dan atmosfer melalui proses evaporasi dan transpirasi. Kelembapan tanah sangat dinamis disebabkan oleh penguapan melalui permukaan tanah, transpirasi, dan perkolasi (Suyono dan Sudarmadi, 1997).

Dinamika atau fluktuasi suhu tanah pada kedalaman tanah berbeda dipengaruhi oleh beberapa faktor seperti radiasi matahari, penutupan lahan atau vegetasi, dan kemiringan lahan (Karyati dan Ardianto, 2016). Fluktuasi suhu dan kelembapan tanah pada kedalaman tanah berbeda dipengaruhi perbedaan tipe penggunaan lahan (Assholihat, dkk., 2019), umur tanaman (Karyati, dkk., 2018), dan kombinasi tanaman atau tegakan (Karyati, dkk., 2019). Penelitian tentang suhu dan kelembapan tanah pada posisi topografi dan kedalaman tanah berbeda di taman kota masih sangat terbatas. Penelitian ini bertujuan untuk menganalisis suhu dan kelembapan tanah pada kedalaman tanah berbeda di Taman Sejati Kota Samarinda.

\section{METODA PENELITIAN}

\subsection{Lokasi dan Waktu Penelitian}

Penelitian ini dilaksanakan di Taman Sejati, Kota Samarinda, Provinsi Kalimantan Timur selama kurang lebih enam (6) bulan yaitu bulan September 2018 hingga Februari 2019. Pengambilan data suhu dan kelembapan tanah dilakukan selama 30 hari yaitu tanggal 8 September hingga 22 Oktober 2018. Peta lokasi penelitian di Taman Sejati ditampilkan pada Gambar 1.

\subsection{Alat Penelitian}

Alat-alat yang digunakan dalam penelitian ini antara lain Environment meter, Global Position System (GPS), 
clinometer, Canopy App, kamera, tally sheet, dan alat tulis menulis.

\subsection{Parameter Penelitian}

Parameter yang diukur dalam penelitian ini adalah suhu tanah dan kelembapan tanah pada posisi topografi (puncak, lereng, dan lembah) dan kedalaman tanah $(5 \mathrm{~cm}, 10 \mathrm{~cm}$, dan 20 m) berbeda.

\subsection{Prosedur Penelitian}

2.4.1. Orientasi lapangan dan penentuan titik pengamatan

Orientasi lapangan bertujuan untuk mengetahui gambaran umum lokasi penelitian. Penentuan titik pengamatan dilakukan untuk menentukan posisi topografi berbeda yang mewakili posisi puncak, lereng, dan lembah di taman kota yang diteliti.
2.4.2. Pengukuran suhu dan kelembapan tanah

Pengukuran suhu dan kelembapan tanah dilakukan menggunakan alat Environment meter. Data suhu dan kelembapan tanah pada posisi topografi berbeda (puncak, lereng, dan lembah) dan kedalaman berbeda $(5 \mathrm{~cm}, 10 \mathrm{~cm}$, dan $20 \mathrm{~cm})$ diambil sebanyak 3 (tiga) kali pengukuran, yaitu pagi hari (pukul 07.00-08.00 WITA), siang hari (pukul 12.00-13.00 WITA), dan sore hari (pukul 16.00-17.00 WITA) selama 30 hari. Cara pengukuran suhu dan kelembapan tanah dilakukan dengan menancapkan ujung sensor Environment meter ke dalam tanah pada tiga kedalaman berbeda yaitu $5 \mathrm{~cm}, 10 \mathrm{~cm}$, dan $20 \mathrm{~cm}$ sebagaimana disajikan pada Gambar 2.

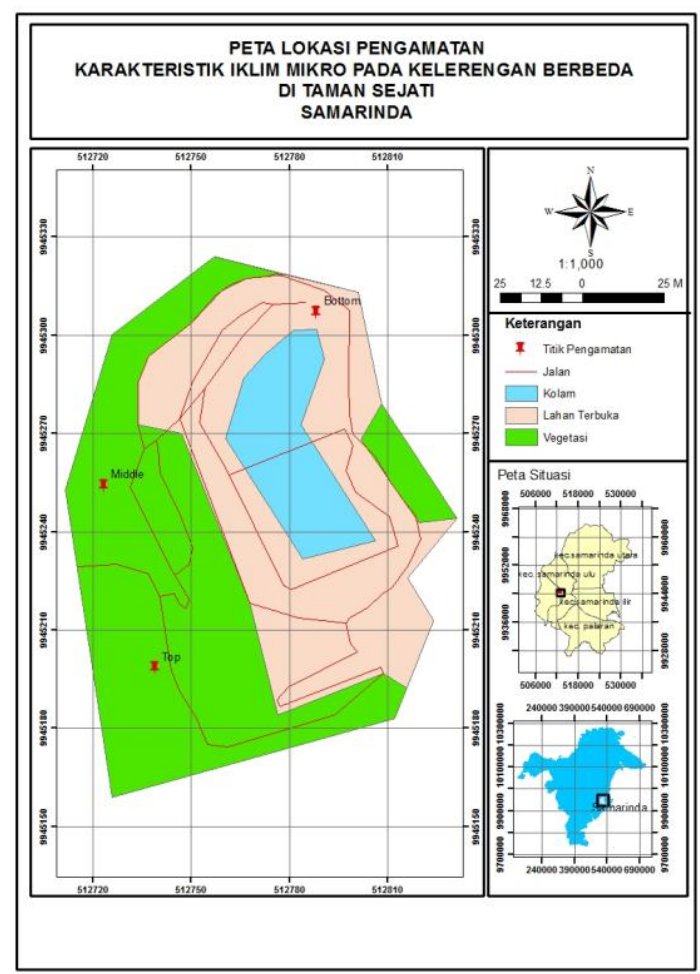

Gambar 1. Peta lokasi penelitian di Taman Sejati, Kota Samarinda, Provinsi Kalimantan Timur. 


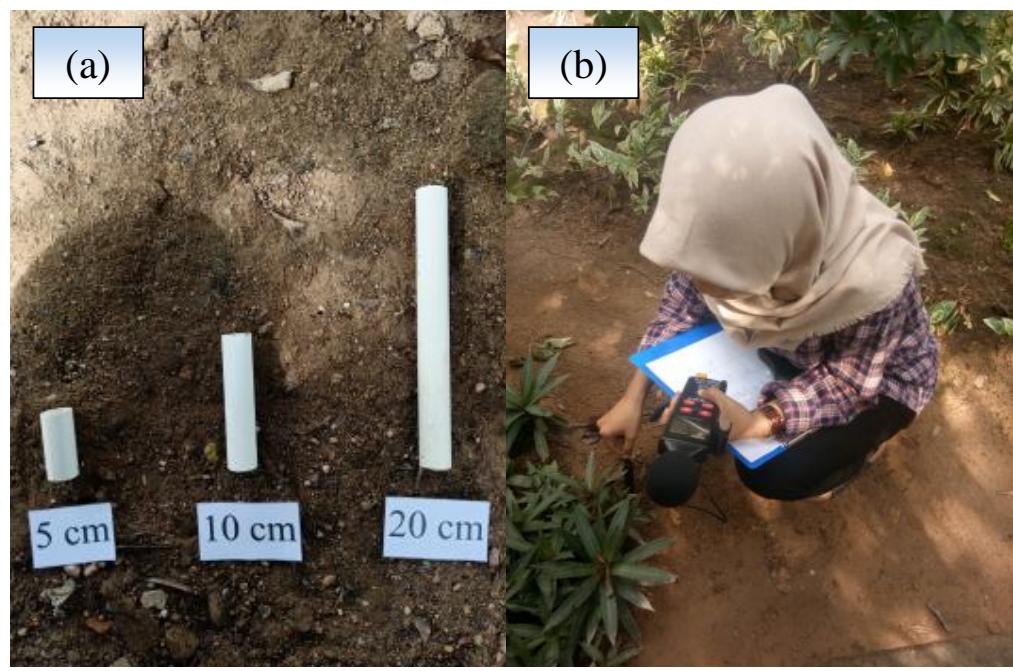

Gambar 2. (a) Lubang pengukuran dan (b) Pengukuran suhu dan kelembapan tanah.

2.5. Analisis Data

Suhu tanah dan kelembapan tanah harian rata-rata dihitung dengan menggunakan rumus (Sabaruddin, 2012):

$$
\bar{T}=\frac{2 \mathrm{~T}_{\text {pagi }}+\mathrm{T}_{\text {siang }}+\mathrm{T}_{\text {gore }}}{4}
$$

Keterangan: $\overline{\mathrm{T}}=$ Suhu tanah harian rata-rata, $\mathrm{T}_{\text {pagi }}, \mathrm{T}_{\text {siang }}$, dan $\mathrm{T}_{\text {sore }}=$ Suhu tanah pada pengukuran pagi, siang, dan sore hari.

$$
\overline{R H}=\frac{2 \mathrm{RH}_{\text {pagi }}+\mathrm{RH}_{\text {siang }}+\mathrm{RH}_{\text {sore }}}{4}
$$

Keterangan: $\overline{\mathrm{RH}}=$ Kelembapan tanah harian rata-rata, $\mathrm{RH}_{\text {pagi }}, \mathrm{RH}_{\text {siang }}$, dan $\mathrm{RH}_{\text {sore }}=$ Kelembapan tanah pada pengukuran pagi, siang, dan sore hari.

Data hasil pengukuran suhu dan kelembapan tanah pada posisi topografi dan kedalaman tanah berbeda disajikan secara deskriptif kuantitatif.

\section{HASIL DAN PEMBAHASAN}

\subsection{Gambaran Umum Lokasi Penelitian}

Taman Sejati merupakan salah satu taman yang terletak di Jalan MT Haryono, Karang Anyar, Kecamatan Sungai Kunjang, Kota Samarinda, Provinsi Kalimantan Timur. Taman Sejati terletak tidak jauh dari pusat Kota Samarinda yang terletak pada titik koordinat $\quad 117^{\circ} 06^{\prime} 51.8^{\prime \prime} \mathrm{BT}$ dan $0^{\circ} 29^{\prime} 42.4 " L S$ dengan luas $35.000 \mathrm{~m}^{2}$.

\subsubsection{Puncak Taman Sejati}

Posisi puncak berada sekitar $14 \mathrm{~m}$ dari pintu gerbang, dengan rute menanjak yang menandakan lokasi ini adalah daerah paling atas yang biasa disebut puncak. Posisi ini merupakan lokasi yang paling rimbun tetapi sangat dekat dengan jalan raya, dimana terdapat banyak pepohonan dengan tajuk antar pepohonan sangat rapat. Pemilihan lokasi titik pengukuran berada dibawah naungan pohon angsana dengan nilai persentase kerapatan tajuk sebesar 35,5\%. 
Tekstur tanah pada di bagian puncak yaitu lempung berpasir dengan kriteria rasa kasar agak jelas, agak melekat, dapat dibuat bola tetapi mudah hancur, dan memiliki struktur tanah granular. Beberapa jenis tumbuhan yang ditemui di lokasi penelitian ini antara lain anggrek dendro (Dendrobium kingianum), anggrek tanah (Bletilla striat), anggrek tebu (Grammatophyllum speciosu), ulin (Eusideroxylon zwageri), cendana (Santalatum album), keladi (Caladium sp.), flamboyan (Delonix regia), lavender (Lavandula), bambu kuning (Phyllostachys sulphurea), ketapang (Terminalia catappa), kerai payung (Filicium decipiens), angsana (Pterocarpus indicus), glodokan (Polyalthia longifolia), tanjung (Mimusops elengi), kersen (Muntingia calabura L.), dan hanjuang pink (Cordyline frusticosa).

\subsubsection{Lereng Taman Sejati}

Posisi lereng terletak di bagian tengah Taman Sejati yang berjarak sekitar $29 \mathrm{~m}$ dari pintu gerbang setelah menuruni anak tangga. Posisi lereng hanya ditumbuhi beberapa pepohonan saja, sehingga kerapatan tajuk antar pepohonan tidak begitu rapat. Pemilihan lokasi titik pengukuran berada di bawah naungan pohon tanjung dengan nilai persentase kerapatan tajuk sebesar $29,0 \%$.

Tekstur tanah pada posisi lereng sama seperti posisi puncak yaitu lempung berpasir dengan kriteria rasa kasar agak jelas, agak melekat, dapat dibuat bola tetapi mudah hancur, dan memiliki struktur granular. Posisi lereng ditumbuhi beraneka tumbuhan hias dan pohonpohon seperti flamboyan (Delonix regia), keladi (Caladium sp.), bunga tasbih (Canna lily), jengger ayam (Celosia cristata), beringin (Ficus benjamina), kerai payung (Filicium decipiens), kersen (Muntingia calabura L.), angsana
(Pterocarpus indicus), kemuning (Murraya paniculata), tanjung (Mimusops elengi), dan pisang bali (Helioconia rostrata).

\subsubsection{Lembah Taman Sejati}

Posisi lembah terletak pada bagian paling bawah dari Taman Sejati berada kurang lebih $96 \mathrm{~m}$ dari pintu gerbang Taman Sejati. Lokasi ini merupakan tempat yang paling ramai dikunjungi karena berada di dekat danau dan terdapat tempat bermain anak-anak. Pepohonan pada posisi lembah sangat sedikit dijumpai, namun lebih didominasi oleh tanaman hias. Pemilihan lokasi titik pengukuran berada di bawah naungan pohon tanjung dengan nilai persentase kerapatan tajuk sebesar $26,8 \%$.

Tekstur tanah pada puncak yaitu lempung liat berpasir dengan kriteria terasa halus dengan sedikit bagian agak kasar, agak melekat, dapat dibentuk bola agak teguh, dapat dibentuk gulungan mudah hancur, dan memiliki struktur gumpal membulat. Lokasi ini relatif terbuka karena jarang ditemui adanya pepohonan, namun terdapat beberapa jenis tumbuhan yang ditemui antara lain rumput gajah (Pennisetum purpureum), lidah buaya (Aloe vera), lavender (Lavandula), tembelekan (Lantana camara), nanas-nanasan (Billbergia nutans), krokot merah (Portulaca oleracea), jaburan putih (Ophiopogon jaburan), ketapang (Terminalia catappa), kerai payung (Filicium decipiens), bambu kuning (Phyllostachys sulphurea), tanjung (Mimusops elengi), bambu jepang (Chiminobambusa quadrangularis), beringin (Ficus benjamina), dan bougenville (Bougainvillea glabra).

\subsection{Suhu Tanah}

Suhu tanah rata-rata berdasarkan tiga waktu pengukuran yaitu pagi hari (pukul 07.00-08.00 WITA), siang hari (pukul 12.00-13.00 WITA), dan sore hari 
(pukul 17.00-18.00 WITA) pada tiga posisi topografi dan kedalaman tanah berbeda ditunjukkan pada Tabel 1 . Intensitas cahaya matahari sangat berpengaruh terhadap suhu bumi, dimana intensitas cahaya matahari berbanding lurus dengan suhu udara. Suhu udara berangsur naik mulai pagi hari hingga menjelang siang hari dan mencapai maksimum sekitar pukul 12 siang. Dua jam setelahnya yakni sekitar pukul 14.00 suhu dominan konstan, setelah itu suhu perlahan mengalami penurunan hingga matahari terbenam. Fluktuasi suhu udara berpengaruh terhadap fluktuasi suhu tanah. Secara umum suhu udara rataan pada posisi puncak lebih rendah dibandingkan suhu udara rataan di posisi lembah dan lereng. Rapatnya tegakan yang terdapat di posisi puncak diduga menyebabkan penurunan suhu udara. Hal ini juga menunjukkan bahwa suhu tanah dipengaruhi oleh kerapatan tegakan, selain posisi topografi dan kedalaman tanah.

Tabel 1. Suhu Tanah Rataan $\left({ }^{\circ} \mathrm{C}\right)$ pada Tiga Posisi Pengukuran dan Waktu Pengukuran Berbeda di Taman Sejati.

\begin{tabular}{ccccc}
\hline \multirow{2}{*}{ Posisi Topografi } & \multirow{2}{*}{ Waktu Pengukuran } & $5 \mathrm{~cm}$ & $10 \mathrm{~cm}$ & $20 \mathrm{~cm}$ \\
\cline { 3 - 4 } & & 27,5 & 27,3 & 27,1 \\
Puncak & Pagi (07.00-08.00 WITA) & 27,7 & 27,5 & 27,0 \\
Lereng & & 27,7 & 27,3 & 26,7 \\
Lembah & & 32,1 & 31,9 & 31,6 \\
Puncak & Siang (12.00-13.00 WITA) & 32,7 & 32,4 & 31,7 \\
Lereng & & 33,1 & 32,9 & 32,6 \\
Lembah & & 29,1 & 28,8 & 28,5 \\
Puncak & Sore (17.00-18.00 WITA) & 29,1 & 29,0 & 28,4 \\
Lereng & & 29,4 & 29,1 & 28,5 \\
Lembah & & & & \\
\hline
\end{tabular}

Suhu tanah rataan mengalami penurunan pada kedalaman tanah yang lebih dalam. Suhu tanah rataan pada kedalaman $10 \mathrm{~cm}$ dan $20 \mathrm{~cm}$ lebih rendah dibandingkan suhu tanah rataan pada kedalamanan $5 \mathrm{~cm}$. Hal ini terjadi posisi topografi berbeda, baik di bagian puncak, lereng, dan lembah. Fluktuasi suhu tanah pada posisi topografi dan kedalaman tanah berbeda selama pengamatan diilustrasikan pada Gambar 3.

Suhu tanah rataan pada kedalaman $5 \mathrm{~cm}, 10 \mathrm{~cm}$, dan $20 \mathrm{~cm}$ yang terukur di Taman Sejati di posisi puncak, lereng, dan lembah masing-masing berkisar $27,8-30,0^{\circ} \mathrm{C}, 27,6-30,4^{\circ} \mathrm{C}$, dan $28,6-31,4^{\circ} \mathrm{C}$. Suhu tanah rataan pada lahan bervegetasi pada kedalaman berbeda lebih rendah dibanding lahan terbuka sebagaimana dilaporkan Karyati dan Ardianto (2016) dan Assholihat, dkk. (2019). Suhu tanah rata-rata pada kedalaman tanah berbeda di dalam hutan lebih kecil $\left(5 \mathrm{~cm}\right.$ berkisar $25,6-27,4^{\circ} \mathrm{C}$, $10 \mathrm{~cm}$ berkisar $25,8-27,2^{\circ} \mathrm{C}, 20 \mathrm{~cm}$ berkisar $24,0-25,0^{\circ} \mathrm{C}$, dan $30 \mathrm{~cm}$ berkisar $24,1-24,9^{\circ} \mathrm{C}$ ) dibandingkan di luar hutan $\left(5 \mathrm{~cm}\right.$ antara $27,9-31,9^{\circ} \mathrm{C}, 10 \mathrm{~cm}$ antara $28,2-31,5^{\circ} \mathrm{C}, 20 \mathrm{~cm}$ antara $27,0-28,1^{\circ} \mathrm{C}$, dan $30 \mathrm{~cm}$ antara $27,0-28,2^{\circ} \mathrm{C}$ ) (Karyati dan Ardianto, 2016). Profil suhu tanah rataan pada kedalaman tanah berbeda (5 $\mathrm{cm}, 10 \mathrm{~cm}, 20 \mathrm{~cm}$, dan $30 \mathrm{~cm}$ ) menunjukkan di lokasi hutan sekunder memiliki nilai terendah dan diikuti oleh pemukiman penduduk dan lahan terbuka (Assholihat, dkk., 2019).

Umur tanaman dan kombinasi tanaman atau tegakan juga diduga berpengaruh terhadap fluktuasi suhu 
tanah pada kedalaman berbeda (Karyati, dkk., 2018 dan Karyati, dkk., 2019). Suhu tanah tertinggi pada kedalaman 10 $\mathrm{cm}$ dan $20 \mathrm{~cm}$ pada lahan revegetasi umur 3 tahun adalah sebesar $27,7^{\circ} \mathrm{C}$ dan $26,6^{\circ} \mathrm{C}$, sedangkan suhu tanah terendah pada kedalaman $10 \mathrm{~cm}$ dan $20 \mathrm{~cm}$ pada lahan revegetasi umur 7 tahun masingmasing sebesar $26,1^{\circ} \mathrm{C}$ dan $24,9^{\circ} \mathrm{C}$
(Karyati, dkk., 2018). Karyati, dkk. (2019) melaporkan suhu tanah pada kombinasi sengon-kacang panjang dan jabon-buncis cenderung menurun dengan bertambahnya kedalaman tanah dimana suhu tanah di bawah tegakan sengonkacang panjang lebih besar dibandingkan di bawah tegakan jabon-buncis.
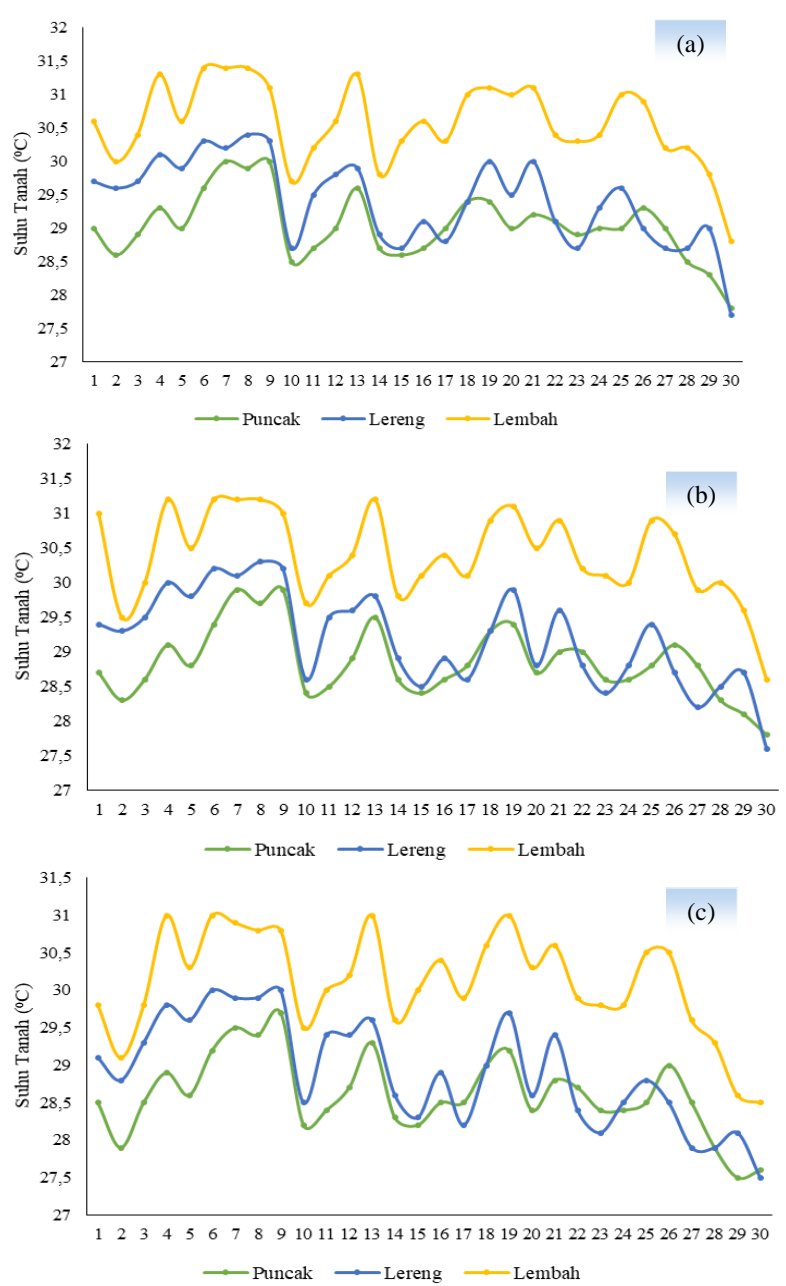

Gambar 3. Suhu Tanah Rataan Harian pada Kedalaman (a) 5 cm, (b) $10 \mathrm{~cm}$, dan (c) $20 \mathrm{~cm}$ di Taman Sejati.

\subsection{Kelembapan Tanah}

Kelembapan tanah rataan pada tiga posisi topografi dan waktu pengukuran disajikan pada Tabel 2. Pengukuran menunjukkan bahwa makin dalam tanah, maka kelembapan tanah makin meningkat. Kecenderungan ini terjadi pada posisi topografi berbeda (puncak, lereng, dan lembah) dan waktu pengukuran berbeda (pagi, siang, dan sore hari). Rendahnya suhu udara di posisi puncak dibandingkan pada posisi lereng dan lembah diduga menyebabkan tingginya kelembapan udara di di posisi puncak dibandingkan lereng dan lembah sebagaimana ditampilkan pada Gambar 4. 
Rimbunnya tajuk pepohonan menyebabkan pergerakan kandungan air hasil evapotranspirasi yang terjadi tidak leluasa bergerak sehingga cenderung membuat kelembapan udara di posisi puncak lebih tinggi. Kelembapan tanah rataan harian selama 30 hari pengukuran pada kedalaman $5 \mathrm{~cm}, 10 \mathrm{~cm}$, dan $20 \mathrm{~cm}$ pada posisi topografi berbeda yaitu puncak, lereng, dan lembah disajikan pada Gambar 4.

Tabel 2. Kelembapan Tanah Rataan (\%) pada Tiga Posisi Topografi dan Waktu Pengukuran di Taman Sejati.

\begin{tabular}{ccccc}
\hline \multirow{2}{*}{ Posisi Topografi } & \multirow{2}{*}{ Waktu Pengukuran } & \multicolumn{3}{c}{ Kedalaman Tanah } \\
\cline { 3 - 5 } & & $5 \mathrm{~cm}$ & $10 \mathrm{~cm}$ & $20 \mathrm{~cm}$ \\
\hline Puncak & Pagi (07.00-08.00 WITA) & 88,2 & 89,5 & 91,2 \\
Lereng & & 87,0 & 88,3 & 91.1 \\
Lembah & & 84,4 & 87,2 & 91,0 \\
\hline Puncak & \multirow{2}{*}{ Siang (12.00-13.00 WITA) } & 66,5 & 74,5 & 84,1 \\
Lereng & & 63,4 & 74,4 & 82,9 \\
Lembah & & 77,6 & 74,2 & 82,4 \\
\hline Puncak & \multirow{3}{*}{ Sore (17.00-18.00 WITA) } & 73,4 & 81,3 & 84,0 \\
Lereng & & 73,2 & 77,3 & 81,3 \\
Lembah & & & 74,1 & 75,7 \\
\hline
\end{tabular}

Kelembapan udara relatif minimum terjadi sesaat setelah intensitas cahaya matahari mencapai maksimum yakni pada siang hari, sama seperti yang terjadi pada suhu udara ketika mencapai maksimum. Hal ini terjadi karena pengaruh suhu yang sangat besar terhadap kelembapan udara relatif (Lakitan, 1994). Sedangkan pada sore hari intensitas cahaya matahari menurun sehingga kelembapan udara meningkat, karena suhu udaranya menurun, dimana jumlah uap air di udara akan tetap, akan tetapi kapasitas maksimum udara mengikat uap air akan menurun sampai kapasitasnya tetap, sama dengan kapasitas jumlah uap air yang terkandung di udara.

Kelembapan tanah rataan pada kedalaman $5 \mathrm{~cm}, 10 \mathrm{~cm}$, dan $20 \mathrm{~cm}$ di Taman Sejati pada posisi puncak berkisar $72,8-90,0 \%$, pada posisi lereng berkisar $64,9-89,7 \%$, dan pada posisi lembah berkisar 67,0-88,7\%. Fluktuasi kelembapan tanah pada kedalaman berbeda dipengaruhi oleh beberapa hal seperti tipe penggunaan lahan, umur tanaman, dan kombinasi tanaman atau tegakan (Assholihat, dkk., 2019; Karyati, dkk., 2018; Karyati, dkk., 2019). Assholihat, dkk. (2019) melaporkan kelembapan tanah rataan semakin meningkat dengan semakin dalamnya tanah, dimana kelembapan tanah terendah diukur pada lahan terbuka diikuti oleh hutan sekunder muda dan pemukiman penduduk. Kelembapan tanah tertinggi pada kedalaman $10 \mathrm{~cm}$ dan $20 \mathrm{~cm}$ masing-masing sebesar $87,8 \%$ dan $88,0 \%$ terukur pada lahan revegetasi umur 7 tahun, sedangkan kelembapan tanah terendah pada kedalaman $10 \mathrm{~cm}(81,3 \%)$ dan $20 \mathrm{~cm}(81,5 \%)$ terukur pada lahan revegetasi umur 3 tahun (Karyati, dkk., 2018). Kelembapan tanah rata-rata pada kedalaman $5 \mathrm{~cm}(77,5 \%), 10 \mathrm{~cm}(77,5 \%)$, $20 \mathrm{~cm}(77,7 \%)$, dan $30 \mathrm{~cm}(77,8 \%)$ di plot sengon-kacang panjang lebih besar dibandingkan pada plot jabon-buncis (76,7\% pada kedalaman $5 \mathrm{~cm}, 77,4 \%$ pada kedalaman $10 \mathrm{~cm}$ dan $20 \mathrm{~cm}$, serta $77,8 \%$ pada kedalaman $30 \mathrm{~cm}$ ) (Karyati, dkk., 2019). 

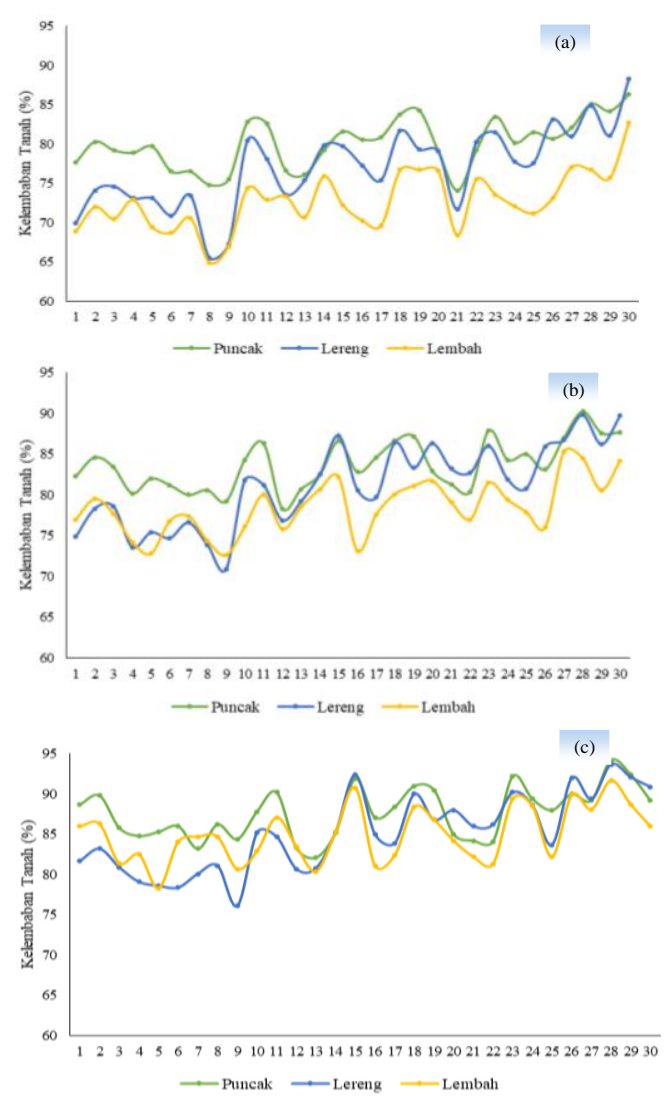

Gambar 4. Kelembapan Tanah Rataan Harian pada Kedalaman (a) 5 cm, (b) $10 \mathrm{~cm}$, dan (c) $20 \mathrm{~cm}$ di Taman Sejati.

Suhu tanah merupakan penentu utama proses yang terjadi di tanah yang diperlukan untuk pertumbuhan tanaman (Onwuka dan Mang, 2018). Prentice (1992) menyatakan bahwa perkembangan dan pertumbuhan tanaman dipengaruhi oleh curah hujan dan evapotranspirasi potensial secara tidak langsung, melalui pengaruhnya terhadap kelembapan tanah. Faktor-faktor lingkungan yang mempengaruhi pertumbuhan berubah secara konstan sepanjang pertumbuhan tanaman seperti kelembapan tanah, kuantitas dan kemampuan larut unsur hara mineral, tingkat keasaman tanah, penyakit, insektisida, suhu udara dan tanah, serta penyinaran (Kasperbauer, 1994). Fluktuasi suhu dan kelembapan tanah dipengaruhi oleh faktor internal, faktor eksternal, dan faktor topografi.
Beberapa hal yang mempengaruhi fluktuasi suhu dan kelembapan tanah adalah posisi topografi, kedalaman tanah, dan kerapatan tajuk tanaman.

\section{KESIMPULAN}

Suhu dan kelembapan tanah bervariasi pada posisi topografi (puncak, lereng, dan lembah) dan kedalaman tanah $(5 \mathrm{~cm}, 10 \mathrm{~cm}$, dan $20 \mathrm{~cm}$ ) berbeda. Suhu tanah mengalami penurunan dengan makin bertambahnya kedalaman, sebaliknya kelembapan tanah mengalami peningkatan seiring dengan peningkatan kedalaman tanah. Fluktuasi suhu dan kelembapan tanah dipengaruhi oleh posisi topografi, kedalaman tanah, dan kerapatan tajuk tanaman. 


\section{DAFTAR PUSTAKA}

Aalto, J., le Roux, P.C., \& Luoto, M. (2013). Vegetation mediates soil temperature and moisture in arcticalpine environments. Arctic, Antarctic, and Alpine Research, 45(4): 429-439.

Arnold, J.E. (1999). Soil Moisture. Tersedia di laman http://www.ghcc.msfc.nasa. gov/landprocess/lp_home.html. Diakses tanggal 04 Februari 2017.

Assholihat, N.K., Karyati, K., \& Syafrudin, M. (2019). Suhu dan kelembaban tanah pada tiga penggunaan lahan di Kota Samarinda, Provinsi Kalimantan Timur. Ulin: Jurnal Hutan Tropis, 3(1): 41-49.

Departemen PU. (2008). Peraturan Menteri Pekerjaan Umum Nomor 05/PRT/M/2008 Tentang Pedoman Penyediaan Dan Pemanfaatan Ruang Terbuka Hijau Di Kawasan Perkotaan.

Imansari, N., \& Khadiyanta, P. (2015). Penyediaan hutan kota dan taman kota sebagai ruang terbuka hijau (RTH) publik menurut preferensi masyarakat di kawasan pusat Kota Tangerang. Jurnal Ruang, 1(3): 101-110.

Karyati dan Ardianto, S. (2016). Dinamika suhu tanah pada kedalaman berbeda di Hutan Pendidikan Fakultas Kehutanan Universitas Mulawarman. Jurnal Riset Kaltim, 4(1): 1-12

Karyati, Putri, R.O., Syafrudin, M. (2018). Suhu dan kelembaban tanah pada lahan revegetasi pasca tambang di PT Adimitra Baratama Nusantara, Provinsi Kalimantan Timur. Agrifor, 17(1): 103-114.
Karyati, Lestari, W.P., \& Syafrudin, M. (2019). Karakteristik suhu dan kelembapan tanah pada kedalaman berbeda di bawah tegakan sengonkacang panjang dan jabon-buncis. Prosiding Seminar Nasional Pertanian 2019 Fakultas Pertanian Universitas Mulawarman. Hal. 1622.

Kasperbauer, M.J. (1994). Light and Plant Development. In Plant Environment Interactions Wilkinson RE, ed.), pp. 83- 123. New York: Marcel Dekker, Inc.

Lakitan, B. (1997). Dasar-dasar Klimatologi. Jakarta: PT Raja Grafindo Persada.

Lubis, K.S. (2007). Aplikasi Suhu dan Aliran Panas Tanah. Medan: Universitas Sumatera Utara.

Onwuka, B. \& Mang, B. (2018). Effects of soil temperature on some soil properties and plant growth. Advances In Plants \& Agriculture Research, 8(1): 34-37.

Prentice, I.C. (1992). Climate Change and Long-term Vegetation Dynamics. In Plant Succession: Theory and Prediction (GlennLewin, D.C., Peet, R.K., \& Veblen, T.T., eds.), pp. 293-339. London: Chapman \& Hall.

Sabaruddin, L. (2012). Agroklimatologi Aspek-aspek Klimatik untuk Sistem Budidaya Tanaman. Bandung: Alfabeta.

Sanger, Y.Y.J., Rogi, J.E.X., \& Rombang, J. (2016). Pengaruh tipe tutupan lahan terhadap iklim mikro di Kota Bitung. Agri-SosioEkonomi Unsrat, 12(3A): 105-116.

Suyono dan Sudarmadil. (1997) Hidrologi Dasar. Yogyakarta: Fakultas Geografi, Universitas Gadjah Mada. 